
ISSN : 2615-1995, E-ISSN : 2615-0654

J. Madani., Vol. 2, No. 1, Maret 2019 (1 - 14)

C2018 Lembaga Kajian Demokrasi

MADANI

dan Pemberdayaan Masyarakat (LKD-PM)

\title{
PENGARUH TEKNIK MENGAJAR DAN PENGUASAAN STRUKTUR KALIMAT TERHADAP KETERAMPILAN MENULIS SISWA PADA SEKOLAH SMP SWASTA DI BOGOR
}

\author{
Juitania \\ Fakultas Ekonomi, Universitas Pamulang \\ juitaniabudiono@ymail.com
}

\begin{abstract}
Abstrak
Tujuan penelitian ini adalah untuk mengetahui efektivitas teknik mengajar terhadap keterampilan menulis siswa, pengaruh penguasaan struktur kalimat yang baik terhadap keterampilan menulis siswa, dan pengaruh interaksi dari penguasaan struktur kalimat terhadap keterampilan menulis siswa. Penelitian ini meenggunakan metode ekperimen. Jumlah sampel peneltian ini adalah 84 siswa yang terdiri dari 42 siswa sebagai kelas eksperimen dan 42 siswa sebagai kelas kontrol, dan teknik pengambilan sampel menggunakan teknik proportional random sampling. Instrumen yang digunakan dalam penelitian ini adalah hasil uji penguasaan struktur kalimat (30 soal) dan keterampilan menulis siswa dalam bentuk esai (1 soal). Penelitian ini menggunakan analisis ANOVA dua jalur. Hasil penelitian menunjukkan bahwa 1). Terdapat pengaruh yang signifikan dari penerapan teknik mengajar terhadap keterampilan menulis siswa SMP SWASTA di Bogor. Hal tersebut dibuktikan dengan Sig. $=0,000<0,05$ and $F_{0}$ is 41,218. 2). Terdapat pengaruh yang signifikan dari penguasaan struktur kalimat terhadap keterampilan menulis siswa SMP SWASTA di Bogor. Hal tersebut dibuktikan dengan Sig. $=0,000<0,05$ and $F_{0}$ is 41,218. 3). Tidak terdapat pengaruh interaksi dari teknik mengajar dan penguasaan struktur kalimat terdahap kekampuan menulis siswa SMP SWASTA di Bogor. Hal tersebut dibuktikan dengan Sig. $=0,106>0,05$ and $F_{0}$ is 2,675.
\end{abstract}

Kata Kunci : mengajar, struktur kalimat, keterampilan menulis, four square.

\begin{abstract}
The purpose of this research is to find out the effect of teaching technique towards students' writing skill, to find out the effect of sentence structure mastery towards students' writing skill, to find out the interactive effect of sentence structure mastery towards students' writing skill. The research methodology is experimental method. Sample size of 84 students consisting of 42 for experiment class and 42 for control class, and the sampling technique used is proportional random sampling. Research instruments used are the test results of sentence structure mastery (30 items) and writing skill essay (1 item). The used test is two-way ANOVA analysis. The results show that: 1). There is a significant effect of teaching technique towards students' writing skill at Private Junior High School in Bogor. It is proved by Sig. $=0,000<0,05$ and $F_{0}$ is 41,218. 2). There is a significant effect of sentence structure mastery towards students' writing skill at Private Junior High School in Bogor. It is proved by Sig. $=0,006<0,05$ and $F_{0}$ is 7,882.3). There are no significant interactive effects of teaching technique and sentence structure mastery towards students' writing skill at Private Junior High School in Bogor. It is proved by Sig. $=0,106>0,05$ and $F_{0}$ is 2,675.
\end{abstract}

Keywords : Teaching, Sentence Structure, Writing Skill, Four Square.

\section{PENDAHULUAN}

Latar Belakang

Bahasa merupakan sarana komunikasi yang dapat menyampaikan informasi, ide atau perasaan dari satu orang ke orang lainnya. Bahasa
Inggris adalah salah satu bahasa yang digunakan diseluruh dunia. Bahasa Inggris digunakan secara luas, hampir disemua negara menggunakannya baik sebagai bahasa pertama, bahasa kedua ataupun sebagai bahasa asing. Bahasa Inggris meru- 
pakan bahasa internasional, bahasa Inggris telah menjadi salah satu mata pelajaran penting yang harus dikuasai oleh siswa dan siswi di Indonesia, baik sebagai penunjang kegiatan pembelajaran atau sebagai ragam bahasa yang digunakan untuk berkomunikasi. Menguasai bahasa Inggris sebagai alat komunikasi dan penyampaian informasi dalam era globalisasi seperti saat ini adalah hal yang penting untuk diaplikasikan kedalam kehidupan sehari-hari.

Seseorang yang menjadikan bahasa Inggris adalah bahasa pertama mereka akan menggunakan bahasa Inggris sebagai bahasa yang dipakai seharihari dalam berkomunikasi.Hal tersebut membuat bahasa Inggris perlu untuk dipelajari oleh siswa dan siswi. Belajar menulis dalam bahasa Inggris sebagai bahasa asing memungkinkan pelajar untuk menyampaikan gagasan mereka dalam sebuah tulisan, membaca tulisan mereka di media cetak, dan menceritakan tulisan mereka pada orang lain. Menulis merupakan cara yang efektif dalam meningkatkan pemerolehan pembelajaran bahasa, melalui menulis siswa dan siswi mencoba menuliskan ide-idenya melalui kata-kata yang dirangkai menjadi kalimat kemudian dijadikan sebagai alat untuk menyampaikan ide-ide mereka kepada pembaca serta untuk memperkaya kosa kata dan mengasah kemampuan tata bahasa para siswa dan siswi dalam menulis pada kegiatan pembelajaran dikelas bahasa Inggris.

Bahasa merupakan sarana yang digunakan dalam berkomunikasi, komunikasi dapat dilakukan dengan cara menulis dan berbicara. Hal tersebut berarti berkomunikasi dapat berbentuk lisan dan tulisan. Menulis adalah salah satu dari empat kemampuan dasar dalam berbahasa yang harus dipelajari oleh para siswa dan siswi dalam belajar bahasa Inggris dan kemampuan menulis memiliki fungsi sebagai media untuk mengekspresikan ide, gagasan, dan perasaan. Brown (2007:334) mengatakan bahwa "belajar menulis adalah sebuah perilaku yang mirip dengan berenang". Brown (2007: 334) states that "writing is a learnt behaviour that is similar to swimming". Orang-orang berbicara seperti perilaku alami mereka, tetapi tidak semua orang dapat menulis semudah berbicara; menulis merupakan keterampilan yang hanya bisa dilakukan secara sadar dan dengan upaya yang kuat. Hal tersebut berarti bahwa berbicara merupakan tindakan, sedangkan kegiatan menulis melibatkan waktu dan tempat dalam menghasilkan sebuah tulisan.

Dalam menulis, seseorang harus memperhatikan struktur kalimat dan juga pilihan kata yang tepat. Menulis tidak seperti berbicara, di dalam berbicara seseorang dapat segera mengklarifikasi dan memberikan penjelasan secara langsung tentang maksud dan tujuan dari pesan yang akan disampaikan kepada orang yang diajak berbicara, sedangkan menulis harus tepat dan konkrit, dan menggunakan beberapa bantuan kamus konvensional atau kamus elektronik untuk membantu menghasilkan tulisan yang baik, sehingga tidak terjadi kesalahpahaman atau salah menafsirkan pesan yang disampaikan kepada pembaca. Selain itu, ketika menulis para siswa dan siswi menjadi mengetahui beragam kosa kata dan struktur kalimat baru, karena mereka melatih kemampuan menulisnya dengan mengekspresikan ide-ide yang ada pada pikiran mereka, tidak hanya menggunakan daya pikir tetapi belajar menulis juga memerlukan dukungan dari organ lain seperti mata dan tangan untuk mencatatkan ide-ide yang akan disampaikan melalui tulisan.

Dalam pemerolehan kemampuan menulis, banyak siswa dan siswi yang menghadapi masalah dalam menulis dan hal tersebut adalah sebuah tantangan untuk mereka untuk menyelesaikan kesulitan dalam pemerolehan kemampuan menulis. Para siswa dan siswi mengasumsikan bahwa menulis adalalah kegiatan yang membosankan, karena ketika menulis mereka terkadang tidak dapat melanjutkan kegiatan menulis dikarenakan terbatasnya ide ketika proses menulis berlangsung dan kebanyakan siswa dan siswi melakukan kesalahan ketika mereka menulis dan menganggap bahwa mengimpretasikan ide menjadi sebuah tulisan adalah tugas yang paling sulit untuk mereka kerjakan. Kesulitan-kesulitan tersebut terjadi disebabkan oleh kurangnya kosa kata yang dimiliki oleh para siswa dan siswi, tidak memiliki pengetahuan tentang teknik penulisan yang baik dan kurang memahami mengenai struktur kalimat dalam bahasa Inggris.

Menulis adalah produk yang dihasilkan dari buah pikiran, penyusunan atau draf, dan revisi apa yang dituliskan yang membutuhkan kemampuan khusus. Siswa dan siswi akan berkembang secara alami dalam memproduksi sebuah paragraf yang baik, para siswa harus mempertimbangkan empat tahapan dalam menulis. Tahapan pertama yaitu perencanaan; didalam tahapan perencanaan para siswa dan siswi harus menentukan topik atau tujuan dari apa yang ingin mereka tulis, memilih diksi atau pilihan kata yang sesuai, dan mempertimbangkan "unity" dan "coherence". Gallo dan Rink (1968:54) mengatakan, "kesatuan yang saling berhubungan antara topik kalimat dan masing-masing dari setiap kalimat-kalimat yang selanjutnya". Gallo and Rink (1968:54) say, "Unity dealt with relationship between the topic sentence and each of sentences that followed". Hal tersebut berarti sebuah paragraf harus mempunyai hubungan antara ide utama dan kalimat pedukungnya. Tidak hanya unity 
tetapi juga koheren adalah bagian penting dalam mengkontruksikan sebuah paragraf karena sebuah kalimat pada paragraf harus saling terkait antara kalimat yang satu dengan kalimat yang lainnya, hal tersebut sejalan dengan pendapat Gallo dan Rink, "Koherensi merupakan hubungan yang terjadi antara kalimat dengan paragraf." "Coherence involves the relationship that occurs from sentence to sentence with the paragraph." Tahapan kedua adalah membuat draf tulisan atau penyususan; para siswa dan siswi menulis garis besar dari teks atau paragraf sebelum mereka membuat teks atau paragraf akhir. Tahapan ketiga adalah proses penyuntingan atau pengeditan, mereka melakukan peninjauan kembali untuk melakukan perbaikan pada teks atau paragraf yang mereka tulis, dan tahapan terakhir adalah publikasi, mereka mempublikasi teks atau paragraf yang mereka tulis.

Ada banyak aspek yang harus dipertimbangkan dalam membuat paragraf atau teks yang baik untuk dipublikasikan, selain empat tahapan; perencanaan, penyusunan atau draf, penyuntingan dan publikasi, penguasaan dalam membuat struktur kalimat adalah salah satu hal penting yang harus diperhatikan oleh para siswa dan siswi dalam menulis. Dengan memahami struktur kalimat bahasa Inggris dengan benar para siswa dan siswi dapat mengkontruksikan kalimat-kalimat dengan baik dan benar maka para siswa dan siswi akan dapat menyampaikan pesan yang mereka tulis kepada para pembaca dengan baik. Tanpa penguasaan struktur kalimat bahasa Inggris yang terorganisir dengan baik dalam menyampaikan pesan melalui bahasa yang komunikatif, baik secara lisan maupun tulisan, bahasa yang tertulis ataupun yang diucapkan akan menjadi kacau. Pada keadaan yang sebenarnya banyak siswa dan siswi yang kurang menguasai struktur kalimat bahasa Inggris, sehingga membuat mereka menhadapi kesulitankesulitan dalam membuat tulisan yang baik dan membutuhkan banyak waktu dalam menulis karena mereka menggunakan struktur kalimat bahasa Inggris yang salah, sehingga mereka tidak dapat menghubungkan kalimat-kalimat yang ditulisnya menjadi paragraf yang koheren, dan mereka juga mereka tidak dapat menyampaikan dan mengembangkan gagasan mereka menjadi tulisan yang dapat dimengerti dan cara yang terorganisir dengan baik, selain itu juga kalimatkalimat yang dibuat merupakan bahasa Indonesia yang diterjemahkan secara harfiah.Hal ini mengakibatkan tulisan yang dihasilkan menjadi tidak memuaskan, kurangnya kosa kata, dan mereka tidak dapat mengekspresikan ide-ide didalam tulisan sesuai dengan tahapan penulisan yang baik dan benar. Terlebih lagi pada tahapan penyuntingan mereka harus memeriksa hasil tulisannya berkali-kali, hal tersebut membuat para siswa dan siswi yang menyerah kemudian berhenti menulis.

Berdasarkan indentifikasi pada permasalahan-permaslahan yang dihadapi para siswa dan siswi dalam pemerolehan kemampuan menulis teks bahasa Inggris sebagai bahasa asing, terdapat beberapa teknik yang biasanya digunakan untuk pengajaran kemampuan menulis. Namun, setiap teknik memiliki kelebihan dan kelemahan. Dalam hal ini peneliti bermaksud untuk mencari tahu efektivitas teknik mengajar; four square writing technique dan penguasaan struktur kalimat bahasa Inggris. Penulis akan meneliti bagaimana four square writing technique dan penguasaan struktur kalimat bahasa Inggris dapat digunakan untuk mendukung dan meningkatkan proses kegiatan belajar dan mengajar secara efektif.

Peneliti mengasumsikan bahwa four square writing technique dan penguasaan struktur kalimat bahasa Inggris dapat menumbuhkan motivasi para siswa dan siswi dalam menyukai keterampilan menulis. Four square writing technique grafik organizer sederhana berbentuk segiempat yang terdiri dari lima kotak yang digunakan untuk mengatur ide atau rencana sebelum mereka menulis sebuah teks yang lengkap terdiri dari ide utama, kalimat-kalimat pendukung, dan kesimpulan. Selain itu penguasaan struktur kalimat adalah hal penting yang harus dikuasai oleh para siswa dan siswi, dengan memahami atau menguasai struktur kalimat bahasa Inggris para siswa dan siswi akan membuat struktur kalimat yang baik dan pesan yang dituliskan akan tersampaikan secara sempurna. Hal-hal tersebut berguna untuk mendukung dan mengembangkan keterampilan menulis para siswa dan siswi.

\section{Pembatasan Masalah}

Peneliti melakukan penelitian yang difokuskan pada efektivitas teknik mengajar dan penguasaan struktur kalimat bahasa Inggris pada keterampilan menulis para siswa dan siswi. Oleh karena itu teknik mengajar yang diteliti pada penelitian ini dibatasi pada teknik four square writing. Sedangkan penguasaan struktur kalimat bahasa Inggris dibatasi pada simple past tense yang diaplikasikan pada recount text; struktur umum dari teks recount adalah menuliskan secara rinci dan mendeskripsikan pengalaman atau peristiwa yang dituliskan berdasarkan kronologi kejadian. Sehingga struktur kalimat bahasa Inggris yang digunakan adalah simple past tense. Materi tersebut berdasarkan silabus yang berlaku dan wajib dipelajari oleh para siswa dan siswi di kelas delapan Sekolah Menengah Pertama. Oleh sebab itu, hal tersebut digunakan oleh peneliti untuk 
mengukur keterampilan menulis para siswa dan siswi di kelas delapan Sekolah Menengah Pertama di Bogor.

\section{METODE}

\section{Tempat dan Waktu Penelitian}

Penelitian ini dilakukan di Sekolah Menengah Pertama Swasta di Bogor kelas delapan semester ganjil pada tahun akademik 2016/2017

\section{Populasi dan Sampel Populasi}

Populasi pada penelitian ini adalah selurus siswa dan siswi kelas delapan Sekolah Menengah Pertama Swasta PGRI 3 Bogor pada tahun akademik 2016-2017 dengan total populasi sebanyak 626 siswa.

\section{Sampel \\ Jumlah Sampel}

Untuk mempermudah kegiatan penelitian dalam pengumpulan data-data, penulis membatasi populasi dengan jumlah sampel tertentu. Dalam pengumpulan data, berdasarkan Arikunto (2006:134) "Apabila subjek kurang dari 100 lebih baik diambil semuanya sehingga penelitianya merupakan penelitian populasi. Jika subjeknya sebesar atau lebih 100 dapat diambil antara 10$15 \%$ atau $20-25 \%$ atau lebih". Berdasarkan pendapat tersebut, maka pengambilan sampel pada penelitian ini adalah sebanyak 84 (delapan puluh empat) siswa dan siswi atau sebesar $13,5 \%$ dari total populasi sebanyak 626 siswa dan siswi.

\section{Teknik Pengumpulan Sampel}

Pada penelitian ini penulis menggunakan proportional random sampling untuk memperoleh sampel sebanyak 84 (delapan puluh empat) siswa dan siswi kelas delapan SMP PGRI 3 Bogor sebagai sampel didalam penelitian; dibagi kedalam kelas eksperimen dan kelas kontrol. Sampel pada penelitian ini dibagi kedalam dua kelompok; kelompok pertama sebanyak 42 (empat puluh dua) siswa dan siswi yang diberikan perlakuan dengan menggunakan teknik mengajar modern dan kelompok kedua sebanyak 42 (empat puluh dua) siswa dan siswi yang diberikan perlakuan dengan menggunaka teknik mengajar konvensional. Masing-masing kelas diberikan dua teknik mengajar yang berbeda; teknik Four Square Writing dan teknik konvensional. Sampel pada penelitian ini dibagi kedalam dua kelompok; kelompok siswa dan siswi yang memiliki kemampuan tinggi dan kemampuan rendah dalam penguasaan struktur kalimat.

\section{Metode Penelitian}

Peneliti menggunakan metode eksperimen untuk meneliti "Pengaruh Teknik Mengajar dan Penguasaan Struktur Kalimat Terhadap Keterampilan Menulis Siswa Pada Sekolah SMP Swasta di Bogor". Pada penelitian ini peneliti menggunakan comparative statistics untuk meneliti Pengaruh Teknik Mengajar dan Penguasaan Struktur Kalimat Terhadap Keterampilan Menulis Siswa Pada Sekolah Smp Swasta di Bogor. Peneliti akan membagi dua kelas; kelas ekperimen dan kelas kontrol. Kelas ekperimen menggunakan teknik mengajar four square writing dan kelas kontrol menggunakan teknik mengajar konvensional dalam kegiataan belajar mengajar.

\section{Desain Penelitian}

Berdasarkan metode penelitian yang digunakan penelitian ini menggunakan faktorial desain $2 \mathrm{X} 2$, sebagai berikut:

\begin{tabular}{|c|c|c|}
\hline \multicolumn{3}{|c|}{ Tabel 1. Model Penelitian } \\
\hline $\begin{array}{c}\text { Penguasaan } \\
\text { Struktur Kalimat }\end{array}$ & $\begin{array}{c}\text { A1 } \\
\text { Four Square Writing }\end{array}$ & A2 Konvensional \\
\hline B1 & & \\
\hline B2 & A1B1 & A2B1 \\
\hline
\end{tabular}

\section{Deskripsi:}

A1 : Four Square Writing Technique

A2 : Konventional

B1 : Penguasaan struktur kalimat (Tingkat tinggi)

B2 : Penguasaan struktur kalimat (Tingkat rendah)

A1B1 : Siswa atau Siswi yang memiliki tingkat penguasaan struktur kalimat tinggi diberi perlakukan mengajar dengan teknik mengajar dengan Four Square Writing Technique.

A2B1 : Siswa atau Siswi yang memiliki tingkat penguasaan struktur kalimat rendah diberikan perlakuan mengajar dengan teknik mengajar Four Square Writing Technique.

A2B2 : Siswa atau Siswi yang memiliki tingkat penguasaan struktur kalimat rendah diberikan perlakuan mengajar dengan teknik mengajar konvensional.

A2B2 : Siswa atau Siswi yang memiliki tingkat penguasaan struktur kalimat tinggi diberikan perlakuan mengajar dengan teknik mengajar konvensional.

\section{Proses Pengumpulan Data}

1. Mempersiapkan RPP, materi, alat penunjang kegiatan mengajar.

2. Melakukan Pre-Test.

3. Menyampaikan materi.

4. Melakukan kegiatan keterampilan menulis menggunakan teknik mengajar; teknik Four 
Square Writing.

5. Melakukan evaluasi hasil pekerjaan menulis dengan teman sebangku.

6. Memberikan pengayaan pada materi yang telah didiskusikan.

7. Melakukan Post-Test.

\section{Teknik Pengumpulan Data}

Variabel Penelitian

Variabel-variabel penelitian tersebut adalah sebagai berikut:

1. Variabel independen 1 atau atau treatment variable (A) yaitu teknik mengajar dengan menggunakan Four Square Writing dan konvensional.

2. Variabel dependen 2 atau attributive variable (B) yaitu penguasaan struktur kalimat dengan menggunakan uji penguasaan struktur kalimat simple past tense.

3. Variabel dependen atau criterion variable yaitu keterampilan menulis siswa yang dirancang dengan standar kurikulum sekolah menengah pertama.

\section{Sumber Data}

Semua data dalam penelitian ini bersumber dari siswa dan siswi. Dalam memperoleh data penelitian, penelitian ini akan dilakukan dengan menggunakan propotional random sampling yang diterapkan pada pengarus teknik mengajar dan penguasaan struktur kalimat pada kemampuan menulis siswa dan siswi pada teks recount. Peneliti memberikan pre-test pada kedua kelas; kelas eksperimen dan kelas kontrol untuk mengetahui prestasi belajar siswa sebelum diberikan perlakuan penerapan teknik mengajar. Peniliti juga memberikan post-test kepada kelas kontrol dan kelas eksperimen setelah kedua kelas tersebut diberikan perlakuan penerapan teknik mengajar. Hasil test tersebut di analisa dengan menggunakan SPSS 21.00. Data penelitian tersebut dapat dilihat pada tabel di bawah ini.

\begin{tabular}{|c|c|}
\hline \multicolumn{2}{|c|}{ Tabel 2. Sumber Data } \\
\hline Variabel Penelitian & Sumber Data \\
\hline Teknik mengajar & Siswa \\
\hline Struktur kalimat & Siswa \\
\hline Kemampuan menulis & Siswa \\
\hline
\end{tabular}

Sumber data dari variabel independen adalah perlakuan menggunakan teknik mengajar dan tes, sedangkan data variabel dependen pada penelitian ini adalah tes kemampuan menulis dari 84 siswa yang merupakan responden penelitian ini.

\section{Teknik Pengumpulan Data}

\begin{tabular}{|c|c|}
\hline \multicolumn{2}{c|}{ Tabel 3. Instrumen Pengumpulan Data } \\
\hline Variabel Penelitian & $\begin{array}{c}\text { Teknik Pengumpulan Data } \\
\text { Teknik mengajar }\end{array}$ \\
$\begin{array}{c}\text { Memberikan perlakuan kepada } \\
\text { setiap kelas; kelas kontrol dan kelas } \\
\text { eksperimen. }\end{array}$ \\
\hline Struktur kalimat & $\begin{array}{c}\text { Tes struktur kalimat } \\
\text { (Tes Pilihan Ganda) }\end{array}$ \\
\hline Kemampuan menulis & Tes kemampuan menulis \\
\hline
\end{tabular}

\section{Instrumen Penelitian \\ Instrumen Penguasaan Struktur Kalimat Definisi Konseptual Variabel}

Struktur kalimat adalah kemampuan dasar untuk menulis. Kemampuan menulis harus dipelajari dengan mempraktikan secara berkala, seperti rasa lapar dan keinginan untuk makan setiap hari. Siswa dan siswi harus memahami pentingnya menerapkan latihan penguasaan struktur kalimat agar mereka dapat menulis agar pesan yang ditulis dapat tersampaikan dengan baik dan dapat dipahami oleh pembaca, dan mereka termotivasi untuk mengetahui keuntungan menguasai struktur kalimat. Penguasaan struktur kalimat yang baik dan benar dapat membantu siswa dan siswi menghasilkan teks atau tulisan untuk berkomunikasi. Dengan kata lain, seseorang yang berlatih secara berkala dan tekun akan dapat menguasai struktur kalimat dengan baik.

\section{Definisi Operasional Variabel}

Para siswa dan siswi diharuskan untuk latihan secara berkala. Mereka diharuskan untuk memiliki keinginan yang tinggi untuk berlatih setiap hari dan secara berkala, berlatih untuk menguasai struktur kalimat yang baik memerlukan minat, dan motivasi untuk menyukai kegiatan penguasaan struktur kalimat. Para siswa dan siswi berada di tingkat rendah dalam menguasai struktur kalimat dan tidak memiliki pengetahuan yang cukup untuk menulis karena mereka tidak mengaplikasikannya secara rutin.

\section{Instrumen Penguasaan Struktur Kalimat}

Peneliti menggunakan menggunakan tes (pertanyaan pilihan ganda) sebagai instrumen penelitian untuk menguji kemampuan struktur kalimat. Tes berisi pertanyaan yang digunakan untuk mendapatkan informasi dari responden berupa laporan tentang keahlian siswa atau pengetahuan siswa. Hal tersebut berarti bahwa tes diberikan kepada siswa dan siswi sebagai instrumen penelitian yang terdiri dari serangkaian pertanyaan untuk mengumpulkan informasi tentang tingkat penguasaan struktur kalimat dari masing-masing responden. Tes (pertanyaan pilihan ganda) diberikan untuk mengukur keterampilan dalam menguasai struktur kalimat tentang simple past 
tense. Dalam mencapai tingkat respon terbaik, pertanyaan harus dimulai dari pertanyaan yang paling mudah ke pertanyaan ke paling sulit, dan dari pertanyaan yang umum ke pertanyaan yang spesifik.

\begin{tabular}{|c|c|c|c|}
\hline \multicolumn{4}{|c|}{$\begin{array}{c}\text { Tabel 4. Rancangan Instrument Penguasaan } \\
\text { Struktur Kalimat sebelum Validasi }\end{array}$} \\
\hline No & Variabel & Indikator & Pertanyaan \\
\hline \multirow[t]{6}{*}{1} & $\begin{array}{l}\text { Penguasaan } \\
\text { struktur } \\
\text { kalimat (Simple } \\
\text { Past Tense) }\end{array}$ & $\begin{array}{l}\text { Siswa dapat memilih } \\
\text { jawaban yang benar dengan } \\
\text { menggunakan kata kerja tidak } \\
\text { beraturan pada kalimat positif. }\end{array}$ & $\begin{array}{l}1,2,3,6,11,13 \\
14,15,18,24,25 \\
27,28,29,34,36 \\
37,41,42,43,44 \\
45,46,47,48,49\end{array}$ \\
\hline & & $\begin{array}{l}\text { Siswa dapat memilih } \\
\text { jawaban yang benar dengan } \\
\text { menggunakan kata kerja tidak } \\
\text { beraturan pada kalimat negatif. }\end{array}$ & $16,19,31$ \\
\hline & & $\begin{array}{l}\text { Siswa dapat memilih } \\
\text { jawaban yang benar dengan } \\
\text { menggunakan kata kerja } \\
\text { beraturan pada kalimat positif. }\end{array}$ & $\begin{array}{l}4,5,8,12,17,21 \\
30,33,35,38 \\
39,40,50\end{array}$ \\
\hline & & $\begin{array}{l}\text { Siswa dapat memilih } \\
\text { jawaban yang benar dengan } \\
\text { menggunakan kata kerja } \\
\text { beraturan pada kalimat negatif. }\end{array}$ & 9,22 \\
\hline & & $\begin{array}{l}\text { Siswa dapat memilih jawaban } \\
\text { yang benar kalimat pertanyaan } \\
\text { dengan kata kerja bentuk } \\
\text { pertama dalam past form. }\end{array}$ & $7,10,20,32$ \\
\hline & & Total & 50 \\
\hline
\end{tabular}

\section{Uji Validitas dan Reliabilitas}

Instrumen penelitian telah dirancang dan melakukan percobaan untuk menentukan tingkat reliabilitas instrumen. Hal ini digunakan untuk mengukur atau menguji dengan pertanyaan pilihan ganda dan esai tes dalam penelitian ini; struktur kalimat menggunakan tes dalam bentuk pertanyaan pilihan ganda dan menulis esai dengan teknik four square. Rangkaian tes meliputi validitas dan uji reliabilitas secara keseluruhan dihitung dengan menggunakan program SPSS 21.00.

\section{Instrumen Validitas}

\section{Penguasaan Struktur Kalimat}

Validitas dari instrumen penguasaan struktur kalimat diukur dengan Pearson Product Moment (Arikunto, 2010:213), formulanya sebagai berikut:

$$
\mathrm{rXY}=\mathrm{N} \sum X Y-\left(\sum X\right)\left(\sum Y\right)
$$

$$
\sqrt{\left\{N \sum X^{2}-\left(\sum X^{2}\right)\right\}\left\{N \sum Y^{2}-\left(\sum Y^{2}\right)\right\}}
$$

R xy : Koefisien korelasi Produk Momen X dan Y

$\sum x \quad$ : Nilai distribusi $\mathrm{X}$

$\sum X^{2}$ : Jumlah kuadrat distribusi $\mathrm{X}$

$\sum y \quad$ : Nilai distribusi $Y$

$\sum Y^{2}$ : Jumlah kuadrat distribusi $Y$

$\mathrm{N}$ : Jumlah responden
Validitas instrumen penguasaan struktur kalimat ditentukan dengan perbandingan antara nilai $r_{x y}$ dengan $r$ Pearson Product Moment, tingkat signifikansi 95\% $\alpha=0,05$ dan derajat kebebasab df $=\mathrm{N}-2 . \mathrm{N}$ adalah jumlah responden dan jika $r_{\text {hitunn }} \geq$ $\mathrm{r}$ tabel. Jadi item dari instrumen dinyatakan valid ketika $r_{\text {hitung }}<r_{\text {tabel }}$ item dari instrumen dinyatakan tidak valid, dan instrumen tersebut tidak digunakan sebagai alat uji untuk para siswa. Hasil menunjukkan $r_{\text {hitung }}>r_{\text {tabep }} ; r_{\text {tabel }}$ is 0,312 (Arikunto, 2010:402) di mana $\mathrm{df}=42-2=40$, dengan tingkat signifikan 95\%. Dalam mengukur validitas alat uji, peneliti menggunakan program SPSS 21.00. Berikut adalah Tabel klasifikasi dari koefisien validitas dan hasil dari validitas setiap item alat

\begin{tabular}{|c|c|c|c|c|}
\hline \multicolumn{5}{|c|}{$\begin{array}{r}\text { Tabel 5. Uji Validitas Penguasaan } \\
\text { Item-Total Statistics }\end{array}$} \\
\hline & $\begin{array}{l}\text { Scale Mean if } \\
\text { Item Deleted }\end{array}$ & $\begin{array}{l}\text { Scale Variance } \\
\text { if Item } \\
\text { Deleted }\end{array}$ & $\begin{array}{l}\text { Corrected } \\
\text { Item-Total } \\
\text { Correlation }\end{array}$ & Description \\
\hline ITEM 1 & 20,43 & 23,714 & 0,446 & Valid \\
\hline ITEM 2 & 20,4 & 24,1 & 0,364 & Valid \\
\hline ITEM 3 & 20,36 & 23,943 & 0,537 & Valid \\
\hline ITEM 4 & 20,43 & 23,47 & 0,52 & Valid \\
\hline ITEM 5 & 20,33 & 24,52 & 0,381 & Valid \\
\hline ITEM 6 & 20,33 & 24,179 & 0,545 & Valid \\
\hline ITEM 7 & 20,43 & 23,714 & 0,446 & Valid \\
\hline ITEM 8 & 20,52 & 23,475 & 0,411 & Valid \\
\hline ITEM 9 & 20,36 & 24,479 & 0,323 & Valid \\
\hline ITEM 10 & 20,69 & 22,853 & 0,48 & Valid \\
\hline ITEM 11 & 20,36 & 24,284 & 0,4 & Valid \\
\hline ITEM 12 & 20,33 & 24,52 & 0,381 & Valid \\
\hline ITEM 13 & 20,81 & 23,524 & 0,326 & Valid \\
\hline ITEM 14 & 20,57 & 22,836 & 0,534 & Valid \\
\hline ITEM 15 & 20,43 & 23,031 & 0,654 & Valid \\
\hline ITEM 16 & 20,69 & 22,853 & 0,48 & Valid \\
\hline ITEM 17 & 20,43 & 22,983 & 0,669 & Valid \\
\hline ITEM 18 & 20,69 & 22,853 & 0,48 & Valid \\
\hline ITEM 19 & 20,36 & 24,333 & 0,381 & Valid \\
\hline ITEM 20 & 20,81 & 23,524 & 0,326 & Valid \\
\hline ITEM 21 & 21,14 & 27,199 & 0,526 & Valid \\
\hline ITEM 22 & 20,6 & 22,198 & 0,672 & Valid \\
\hline ITEM 23 & 20,62 & 22,729 & 0,533 & Valid \\
\hline ITEM 24 & 20,67 & 23,106 & 0,43 & Valid \\
\hline ITEM 25 & 20,81 & 23,524 & 0,326 & Valid \\
\hline ITEM 26 & 20,79 & 23,49 & 0,333 & Valid \\
\hline ITEM27 & 20,55 & 22,303 & 0,685 & Valid \\
\hline ITEM 28 & 20,74 & 22,442 & 0,562 & Valid \\
\hline ITEM 29 & 20,69 & 22,853 & 0,48 & Valid \\
\hline ITEM 30 & 20,79 & 23,49 & 0,333 & Valid \\
\hline
\end{tabular}
uji atau tes.

Terdapat 30 pertanyaan untuk uji penguasaan struktur kalimat setelah dilakukan perhitungan 
uji validitas terhadap instrumen tersebut, dengan hasil sebagai berikut:

\begin{tabular}{|c|c|c|c|}
\hline \multicolumn{4}{|c|}{$\begin{array}{l}\text { Tabel 6. Rancangan Instrument Penguasaan } \\
\text { Struktur Kalimat setelah Validasi }\end{array}$} \\
\hline No & Variabel & Indikator & Pertanyaan \\
\hline \multirow[t]{6}{*}{1} & $\begin{array}{l}\text { Penguasaan } \\
\text { Struktur } \\
\text { Kalimat (Simple } \\
\text { Past Tense) }\end{array}$ & $\begin{array}{l}\text { Siswa dapat memilih } \\
\text { jawaban yang benar dengan } \\
\text { menggunakan kata kerja tidak } \\
\text { beraturan pada kalimat positif. }\end{array}$ & $\begin{array}{l}1,2,3,5,10,11 \\
13,16,18,20,21 \\
22,28,29\end{array}$ \\
\hline & & $\begin{array}{l}\text { Siswa dapat memilih } \\
\text { jawaban yang benar dengan } \\
\text { menggunakan kata kerja tidak } \\
\text { beraturan pada kalimat negatif. }\end{array}$ & 24 \\
\hline & & $\begin{array}{l}\text { Siswa dapat memilih } \\
\text { jawaban yang benar dengan } \\
\text { menggunakan kata kerja } \\
\text { beraturan pada kalimat positif. }\end{array}$ & $\begin{array}{l}4,7,12,23,26 \\
27,30\end{array}$ \\
\hline & & $\begin{array}{l}\text { Siswa dapat memilih } \\
\text { jawaban yang benar dengan } \\
\text { menggunakan kata kerja } \\
\text { beraturan pada kalimat negatif. }\end{array}$ & 8,14 \\
\hline & & $\begin{array}{l}\text { Siswa dapat memilih jawaban } \\
\text { yang benar kalimat pertanyaan } \\
\text { dengan kata kerja bentuk } \\
\text { pertama dalam past form. }\end{array}$ & $6,9,15,17,19,25$ \\
\hline & & Total & 30 \\
\hline
\end{tabular}

\section{Uji Instrumen Reliabilitas Penguasaan Struktur} Kalimat

Uji reliabilitas terhadap penguasaan struktur kalimat diuji dengan menggunakan perhitungan KR-20, formula alat ukur adalah sebagai berikut:

$\mathrm{r}_{11}=\left(\frac{K}{K-1}\right)\left(\frac{V t-\sum p q}{V t}\right)$

$\mathrm{r}_{11}=$ Reliabilitas instrumen yang dicari

$\mathrm{K}=$ Jumlah instrument yang diuji

$\mathrm{Vt}=$ total varian

$\mathrm{P}=$ proposi subjek yang menjawab pertanyaan dengan benar (proposri subjek yang mendapat nilai 1 )

$\mathrm{Q}=$ proporsi subjek yang mendapat nilai 0

Hasil $r_{11}$ dikonfersikan dengan menggunakan tabel $\mathrm{r}$ product moment dengan tingkat signifikansi sebesar $5 \%$, jika $\mathrm{r}_{11}>\mathrm{r}_{\text {tabel }}$ instrumen penelitian tersebut adalah reliable dan sebaliknya (Arikunto, 2010).

Persyaratan instrumen penelitian dikatakan valid adalah jika nila a lebih besar dari pada $\mathrm{r}_{\text {tabel }}$. Jika instrumen dinyatakan reliabel jika nilai $\alpha>$ 0,7 . Reliabilitas dari penguasaan struktur kalimat pada penelitian ini dihitung dengan menggunakan program SPSS 21.00. Berikut adalah tabel hasil uji reliabilitas:

Tabel 7. Uji Reliabiltas Siswa pada Penguasaan Struktur Kalimat

\begin{tabular}{|c|c|}
\hline \multicolumn{2}{|c|}{ Reliability Statistics } \\
\hline Cronbach's Alpha & N of Items \\
\hline, 833 & 30 \\
\hline
\end{tabular}

Berdasarkan tabel diatas, hasil Cronbach
Alpha $>\mathrm{r}_{\text {tabel }} 0,833>0,7$. Hal tersebut menunjukkan bahwa instrumen uji penguasaan struktur kalimat memiliki tingkat reliabilitas yang tinggi.

\section{Instrumen Keterampilan Menulis Definisi Konseptual}

Keterampilan menulis merupakan keterampilan yang harus dikuasai oleh para siswa. Menurut Oshima dan Houge (1997:6) "keterampilan menulis adalah aktivitas yang berkesinambungan" Oshima dan Houge (1997:6) "Writing is a progressive activity". Hal tersebut berarti para siswa mengetahui apa yang akan ditulis dan mengeksplorasi apa yang ada di dalam pikiran. Terlebih lagi, menulis juga merupakan alat komunikasi antar penulis dan pembaca; melalui tulisan dapat menyampaikan pesan penulis kepada para pembaca. Reid (2001:13) menyatakan bahwa "menulis adalah bentuk komunikasi; menulis merupakan proses edukasi antara penulis dan pembaca, dimana seorang penulis bertanggung jawab terhadap pesan yang ingin dikomunikasikan kepada pembaca". Reid states that (2001:13) "writing is a practical form of communication; writing is an educational process for both the writer and reader, in which the writer is responsible for successful communication".

\section{Definisi Operasional}

Peneliti berharap agar para siswa dapat mengeksplorasi ide atau pikiran mereka ke dalam paragraf yang memiliki arti atau makna dan mereka dapat memahami dan mengaplikasikan struktur kalimat, tenses, tanda baca, penulisan kata, huruf kapita dengan benar pada keterampilan menulis dalam menulis sebuah teks.

\section{Instrumen Keterampilan menulis}

Membuat sebuah teks adalah alat uji yang akan digunakan pada penelitian ini sesuai dengan pendapat dari Brown (2001:384) yang menyatakan bahwa "tes adalah metode untuk mengukur kemampuan atau pengetahuan dalam ranah tertentu". Brown (2001: 384), "Test is a method of measuring a person's ability or knowledge in a given domain." Tes tersebut diberikan untuk mengukur prestasi keterampilan menulis siswa. The test is given to measure achievement of students' writing skill.

Peneliti menggunakan ESL (English Second Language) composition profile yang bersumber dari Reid (1993: 2360237) untuk menilai kemampuan siswa dalam menulis teks recount.

\begin{tabular}{l|c|c|l|}
\hline \multicolumn{3}{c|}{ Tabel 8. Pedoman Penilaian Keterampilan Menulis } \\
\hline CONTENT & 30 & $30-27$ & $\begin{array}{l}\text { Excellent to very good: } \\
\text { knowledgeable, develop of the thesis, } \\
\text { relevant to assigned topic. }\end{array}$ \\
\hline
\end{tabular}




\begin{tabular}{|c|c|c|c|}
\hline & & $26-22$ & $\begin{array}{l}\text { Good to average: sure knowledge } \\
\text { of subject, adequate range, limited } \\
\text { development of thesis, mostly relevant } \\
\text { to topic but lacks detail. }\end{array}$ \\
\hline & & $21-17$ & $\begin{array}{l}\text { Fair to poor: limited knowledge of } \\
\text { subject, little substance, inadequate } \\
\text { development of topic. }\end{array}$ \\
\hline & & $16-13$ & $\begin{array}{l}\text { Very poor: doesn't show knowledge } \\
\text { of subject, non substantive, non } \\
\text { pertinent, or not enough to evaluate. }\end{array}$ \\
\hline \multirow[t]{4}{*}{ ORGANIZATION } & 20 & $20-18$ & $\begin{array}{l}\text { Excellent to very good: fluent } \\
\text { expression, ideas clearly stated/ } \\
\text { supported, succinct, well organized, } \\
\text { logical sequencing, cohesive }\end{array}$ \\
\hline & & $17-14$ & $\begin{array}{l}\text { Good to average: somewhat, copy, } \\
\text { loosely organized, logical but main } \\
\text { idea stand out, limited support, logical } \\
\text { but incomplete sequencing. }\end{array}$ \\
\hline & & $13-10$ & $\begin{array}{l}\text { Fair to poor: non - fluent, ideas } \\
\text { confused or disconnected, lack logical } \\
\text { sequencing and development. }\end{array}$ \\
\hline & & $9-7$ & $\begin{array}{l}\text { Very poor: doesn't communicated, } \\
\text { no organization or not enough to } \\
\text { evaluate. }\end{array}$ \\
\hline \multirow[t]{4}{*}{ VOCABULARY } & \multirow[t]{4}{*}{20} & $20-18$ & $\begin{array}{l}\text { Excellent to very good: sophisticated } \\
\text { range, effective word / idiom choice } \\
\text { and usage, word form mastery, } \\
\text { appropiate register. }\end{array}$ \\
\hline & & $17-14$ & $\begin{array}{l}\text { Good to average: adequate range, } \\
\text { occasional errors or word/ idiom form, } \\
\text { choice, usage, meaning confused or } \\
\text { obscured. }\end{array}$ \\
\hline & & $13-10$ & $\begin{array}{l}\text { Fair to poor: limited range, frequent } \\
\text { errors of word / idiom form, choice, } \\
\text { usage, meaning confused or obscured. }\end{array}$ \\
\hline & & $9-7$ & $\begin{array}{l}\text { Very poor: essentially translation, } \\
\text { little knowledge of English vocabulary, } \\
\text { idioms, word form, or not enough to } \\
\text { evaluate. }\end{array}$ \\
\hline \multirow[t]{4}{*}{ LANGUAGE USE } & \multirow[t]{4}{*}{25} & $25-22$ & $\begin{array}{l}\text { Excellent to very good: effective, } \\
\text { complex construction, few errors } \\
\text { of agreement, tense, number, word } \\
\text { order/ function, articles, pronouns } \\
\text { prepositions. }\end{array}$ \\
\hline & & $21-18$ & $\begin{array}{l}\text { Good to average: effective but simple } \\
\text { construction, minor problems in } \\
\text { complex construction, several errors } \\
\text { of agreement, tense, number, word } \\
\text { order/function, articles, pronouns, } \\
\text { prepositions but meaning seldom } \\
\text { obscured. }\end{array}$ \\
\hline & & $17-11$ & $\begin{array}{l}\text { Fair to poor: major problem in simple/ } \\
\text { complex of negation, agreement, } \\
\text { tense, number, word order/ function, } \\
\text { articles pronouns, preposition and/ or } \\
\text { fragments, runons, deletions, meaning } \\
\text { confused or obscured. }\end{array}$ \\
\hline & & $10-5$ & $\begin{array}{l}\text { Very poor: virtually no mastery } \\
\text { of sentence construction rules, } \\
\text { nominated errors, doesn't } \\
\text { communicative or not enough to } \\
\text { evaluate. }\end{array}$ \\
\hline \multirow[t]{3}{*}{ MECHANICS } & 5 & 5 & $\begin{array}{l}\text { Excellent to very good: demonstrate } \\
\text { mastery of conventions few errors of } \\
\text { spelling, punctuation, capitalization, } \\
\text { paragraphing. }\end{array}$ \\
\hline & & 4 & $\begin{array}{l}\text { Good to average: occasionals errors } \\
\text { of spelling, punctuation, capitalization, } \\
\text { paragraphing, but meaning not } \\
\text { obscured. }\end{array}$ \\
\hline & & 3 & $\begin{array}{l}\text { Fair to poor: frequent errors } \\
\text { spelling,punctuation, capitalization, } \\
\text { paragraphing, poor handwriting, } \\
\text { meaning confused or obscured. }\end{array}$ \\
\hline
\end{tabular}

\begin{tabular}{|l|l|l|l|}
\hline & 2 & $\begin{array}{l}\text { Very poor: no mastery or } \\
\text { conventions, dominated by errors } \\
\text { spelling, punctuation, capitalization, } \\
\text { paragraphing, handwriting illegible, or } \\
\text { not enough to evaluate. }\end{array}$ \\
\hline
\end{tabular}

Instrumen penelitian yang digunakan pada penelitian ini adalah uji penulisan esai. Esai atau uji menulis wajib terdiri dari struktur umum dari teks recount; orientation, events, reorientation sebagai berikut:

\begin{tabular}{|c|c|c|c|}
\hline \multicolumn{3}{|c|}{ Tabel 9. Instrumen Keterampilan Menulis Teks Recount } \\
\hline Variabel & Teks & Indikator & Item \\
\hline $\begin{array}{c}\text { Four square } \\
\text { writing }\end{array}$ & Recount Text & $\begin{array}{c}\text { Orientation, } \\
\text { Events, } \\
\text { Reorientation }\end{array}$ & 1 \\
\hline
\end{tabular}

\section{Uji Validitas dan}

Reliabilitas Keterampilan Menulis Validitas Instrumen Keterampilan Menulis

Validitas adalah ukuran yang mengindikasikan tingkat dari validitas instrumen. Formula yang digunakan untuk mendapatkan hasil alat uji yang valid adalah menggunakan Pearson Product Moment Correlation (Arikunto, 2010:213).

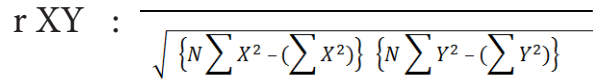 \\ r XY : Koefisien korelasi Produk Momen X dan Y \\ $\sum \mathrm{x} \quad$ : Nilai distribusi $\mathrm{X}$ \\ $\sum \mathrm{X}^{2}$ : Jumlah kuadrat distribusi $\mathrm{X}$ \\ $\sum y \quad$ : Nilai distribusi $Y$ \\ $\sum \mathrm{Y}^{2}$ : Jumlah kuadrat distribusi $\mathrm{Y}$ \\ $\mathrm{N}$ : Jumlah responden}

Hasil yang diperoleh dengan tingkat kepercaan product moment $\mathrm{r}_{\text {tabel }}$ pada $95 \%(\alpha=0,05)$ untuk tingkat signifikan sebesar $5 \%$ berarti bahwa probabilitas kesalahan adalah sebesar 5\% dan hipotesis diterima adalah 95\% berdasarkan dari formula yang digunakan dan derajat kebebasan dinyatakan dengan $\mathrm{df}=\mathrm{N}-2$. Dimana $\mathrm{N}$ adalah total responden. Validitas dari instrumen keterampilan menulis teks recount ditentukan dengan membandingkan nilai $\mathrm{r}_{\mathrm{xy}}$ dengan $\mathrm{r}$ Pearson Product Moment pada $\mathrm{df}=40-2=40$. Jika $\mathrm{r}_{\text {hitung }} \geq$ $\mathrm{r}_{\text {tabel }}$ jadi item instrumenn adalah valid sedangkan jika $\mathrm{r}_{\text {hitung }}<\mathrm{r}_{\text {tabel }}$ jadi item instrumen tidak valid. Hasilnya adalah $\mathrm{r}_{\text {hitung }}>\mathrm{r}_{\text {tabel }} ; \mathrm{r}_{\text {tabel }}$ adalah 0,312 (Arikunto, 2010:402) dimana $\mathrm{df}=42-2=40$, dengan tingkat signifikan 95\%. Dalam pengukura uji validitas peneliti menggunakan program SPSS 21.00. Berikut adalah tabel klasifikasi koefisien validitas dan hasil uji validitas. 


\begin{tabular}{|c|c|}
\hline \multicolumn{2}{|c|}{ Tabel 10. Klasifikasi Koefisien Validitas } \\
\hline Nilia Thitung & Interpretasi \\
\hline $0.90 \leq r_{\text {hitung }} \leq 1.00$ & Highest Validity \\
\hline $0.70 \leq r_{\text {hitung }} \leq 0.90$ & High Validity \\
\hline $0.40 \leq r_{\text {hitung }} \leq 0.70$ & Mid Validity \\
\hline $0.20 \leq r_{\text {hitung }} \leq 0.40$ & Low Validity \\
\hline $0.00 \leq r_{\text {hitung }} \leq 0.20$ & Lowest Validity \\
\hline$r_{\text {hitung }} \leq 0.00$ & Invalid \\
\hline
\end{tabular}

\section{Tabel 11. Uji Validitas Keterampilan Menulis Siswa}

\begin{tabular}{|c|c|c|c|c|}
\hline & $\begin{array}{c}\text { Scale Mean if } \\
\text { Item Deleted }\end{array}$ & $\begin{array}{c}\text { Scale Variance } \\
\text { if Item } \\
\text { Deleted }\end{array}$ & $\begin{array}{c}\text { Corrected } \\
\text { Item-Total } \\
\text { Correlation }\end{array}$ & Description \\
\hline Content & 52,00 & 42,098 &, 780 & Valid \\
\hline Organization & 58,45 & 57,473 &, 777 & Valid \\
\hline Grammar & 58,40 & 56,735 &, 760 & Valid \\
\hline Vocabulary & 56,43 & 45,812 &, 793 & Valid \\
\hline Mechanic & 70,62 & 71,754 &, 697 & Valid \\
\hline
\end{tabular}

Reliabilitas Instrumen Keterampilan Menulis

Uji Reliabilitas dilakukan untuk menentukan konsistensi interval anatara variabel dan instrumen. Uji reliabilitas interval mengunakan metode Cronbach Alpha, sebagai berikut:

$\mathrm{r} 11=\left(\frac{K}{(K-1)}\right)\left(1-\frac{\sum \sigma b^{2}}{\sigma^{2} t}\right)$

r11 = Reliabiltas instrumen

$\mathrm{K}=$ Jumlah pertanyaa

$\sum \sigma \mathrm{b}^{2}=$ Jumlah berbagai Varian

$\sigma^{2} \mathrm{t}=$ Total Varian

Persyaratan instrumen dinyatakan reliabel adalah jika nilai $\alpha$ lebih besar dari rtabel. Instrumen dinyatakan reliabilitas jika nilai $\alpha>0,7$. Reliabilitas keterampilan menulis dihitung dengan menggunakan program SPSS 21.00. Hasil uji reliabilitas ditunjukkan pada tabel di bawah ini:

\begin{tabular}{|c|c|}
\hline \multicolumn{2}{c|}{ Tabel 12. Uji Reliabilitas Keterampilan Menulis Siswa } \\
\multicolumn{2}{|c|}{ Reliability Statistics } \\
\hline Cronbach's Alpha & N of Items \\
\hline, 871 & 5 \\
\hline
\end{tabular}

Berdasarkan tabel diatas, nilai Cronbach Alpha $>\mathrm{r}_{\text {tabel }} 0,871>0,7$. Hal tersebut menunjukkan bahwa uji instrumen tersebut memiliki tingkat reliabiltas yang tinggi.

\section{HASIL dan PEMBAHASAN \\ Hasil \\ Deskripsi Data Hasil Penelitian}

Penelitian ini adalah penelitian eksperimen dua faktor, yaitu teknik mengajar (A) dan penguasaan struktur kalimat bahasa Inggris (B). Masing-masing faktor terdiri dari sub faktor yaitu teknik mengajar dan tingkatan atau level.
Terdapat dua teknik yang diterapkan didalam teknik mengajar (A) yaitu teknik mengajar dengan menggunakan teknik four square writing (A1) dan teknik mengajar konvensional (A2). Penguasaan struktur kalimat bahasa Inggris (B) terdiri dari dua level; penguasaan struktur kalimat bahasa Inggris level tinggi (B1) dan penguasaan struktur kalimat bahasa Inggris level rendah (B2).

Ringkasan data deskriptif berdasarkan data dari setiap variabel yang digunakan untuk proses analsis dapat dilihat pada tabel di bawah ini:

\begin{tabular}{|c|c|c|c|c|}
\hline \multicolumn{4}{|c|}{ Tabel 13. The summary of descriptive statistics } \\
\hline \multicolumn{4}{|c|}{ Destive Statistics } \\
\hline Dependent Variable: Students' Writng Skill \\
\hline \multirow{2}{*}{$\begin{array}{c}\text { Teaching } \\
\text { Technique }\end{array}$} & $\begin{array}{c}\text { Sentence } \\
\text { Structure } \\
\text { Mastery }\end{array}$ & Mean & $\begin{array}{c}\text { Std. } \\
\text { Deviation }\end{array}$ & N \\
\hline \multirow{3}{*}{$\begin{array}{c}\text { Four Square } \\
\text { Writing }\end{array}$} & High Level & 73,09 & 10,991 & 28 \\
\cline { 2 - 5 } & Low Level & 69,64 & 10,926 & 14 \\
\cline { 2 - 5 } & Total & 71,94 & 10,960 & 42 \\
\hline \multirow{4}{*}{\begin{tabular}{c} 
Konvensional \\
\cline { 2 - 5 }
\end{tabular}} & High Level & 59,00 & 15,632 & 17 \\
\cline { 2 - 5 } & Low Level & 45,92 & 14,056 & 25 \\
\hline \multirow{3}{*}{ Total } & Total & 51,21 & 15,914 & 42 \\
\cline { 2 - 5 } & High Level & 67,76 & 14,515 & 45 \\
\cline { 2 - 5 } & Low Level & 54,43 & 17,276 & 39 \\
\hline & Total & 61,58 & 17,119 & 84 \\
\hline
\end{tabular}

Berdasarkan data di atas, keterampilan menulis bahasa Inggris para siswa dan siswi yang diajar dengan teknik four square writing dan memiliki keterampilan penguasaan struktur kalimat yang tinggi dengan jumlah sebanyak 28 (dua puluh delapan) siswa mendapatkan ratarata skor 73.09 dan dengan standar deviasi sebesar 10.991. Sedangkan para siswa dan siswi yang diajar menggunakan teknik four square writing dan memiliki keterampilan penguasaan struktur kalimat yang rendah dengan jumlah sebanyak 14 empat belas siswa mendapatkan rata-rata skor 69,64 dan standar deviasi sebesar 10.926. Mengacu pada deskripsi data statistik yang telah dijelasakan tersebut para siswa dan siswi yang diajar dengan teknik mengajar konvensional dan memiliki keterampilan penguasaan struktur kalimat yang tinggi dengan jumlah sebanyak 17 tujuh belas siswa mendapatkan ratarata skor 59 dan dengan standar deviasi sebesar 15.632. Sedangkan, para siswa dan siswi yang diajar dengan teknik mengajar konvensional dan memiliki keterampilan penguasaan struktur kalimat yang rendah yaitu sebanyak 25 dua puluh lima siswa dan mendapatkan rata-rata skor 45,92 dan dengan standar deviasi sebesar 14.056. 


\section{Tabel 14. Descriptive statistics based on research design}

\begin{tabular}{|c|c|c|c|c|}
\hline \multirow{2}{*}{ B } & \multirow{2}{*}{ Stat } & \multicolumn{2}{|c|}{$\mathrm{A}$} & \multirow{2}{*}{ Total } \\
\cline { 2 - 4 } & & $\mathrm{A} 1$ & $\mathrm{~A} 2$ & \\
\hline \multirow{3}{*}{ B1 } & $\mathrm{N}$ & 28 & 17 & 45 \\
\cline { 2 - 5 } & $\mathrm{X}^{-}$ & 73,09 & 59 & 67,76 \\
\cline { 2 - 5 } & $\mathrm{S}$ & 10,991 & 15,632 & 14,515 \\
\hline \multirow{3}{*}{ B2 } & $\mathrm{N}$ & 14 & 25 & 39 \\
\cline { 2 - 5 } & $\mathrm{X}^{-}$ & 69,64 & 45,92 & 54,43 \\
\cline { 2 - 5 } & $\mathrm{S}$ & 10,926 & 14,056 & 17,276 \\
\hline \multirow{3}{*}{ Total } & $\mathrm{N}$ & 42 & 42 & 84 \\
\cline { 2 - 5 } & $\mathrm{X}^{-}$ & 71,94 & 51,21 & 61,58 \\
\cline { 2 - 5 } & $\mathrm{S}$ & 10,96 & 15,914 & 17,119 \\
\hline
\end{tabular}

\section{Teknik dan Pengujian Data Analisis} Uji Normalitas

Uji normalitas pada data penelitian ini dihitung dengan menggunakan SPSS 21.0. Uji normalitas pada dependen variable atau covariate variabel adalah diperlukan didalam penelitian ini. Jika data yang dihasilkan ada pada uji normalitas atau uji distribusi, maka harus melakukan uji lanjut. Penelitian ini menggunakan parametric analysis or analysis of variance (ANOVA), Di bawah ini adalah kesimpulan dari uji normalitas pada setiap kelompok keterampilan menulis para siswa dan siswi:

\begin{tabular}{|c|c|c|}
\hline \multicolumn{3}{|c|}{ Tabel 15. Uji Normalitas } \\
\hline \multicolumn{3}{|c|}{ One-Sample Kolmogorov-Smirnov Test } \\
\hline & & $\begin{array}{c}\text { Students' } \\
\text { Writing Skill }\end{array}$ \\
\hline \multicolumn{2}{|l|}{$\mathrm{N}$} & 84 \\
\hline Normal & Mean & 61,58 \\
\hline Parameters $\mathrm{a}^{\mathrm{a}, \mathrm{B}}$ & Std. Deviation & 17,119 \\
\hline Most Extreme & Absolute & ,102 \\
\hline \multirow[t]{2}{*}{ Differences } & Positive & 101 \\
\hline & Negative &,- 102 \\
\hline \multicolumn{2}{|c|}{ Kolmogorov-Smirnov Z } & 934 \\
\hline \multicolumn{2}{|c|}{ Asymp. Sig. (2-Tailed) } & ,348 \\
\hline \multicolumn{3}{|c|}{ A. Test Distribution Is Normal. } \\
\hline \multicolumn{3}{|c|}{ B. Calculated From Data. } \\
\hline
\end{tabular}

Berdasarkan tabel hasil uji normalitas diatas, dapat diihat secara jelas pada tingkat signifikansi Kolmogorov-Smirnov Z adalah 0,934 ( $\mathrm{Sig}=0,348$ adalah lebih besar dari 0,05), berdasarkan hal tersebut dapat disimpulkan bahwa semua data yang diuji telah berada pada distribusi normal.

\section{Uji Homogenitas}

Salah satu syarat yang sangat penting selain menganalisa uji normalitas yaitu melakukan uji homogenitas. Tujuan dari uji homogenitas yang dilakukan pada penelitian ini adalah untuk mengetahui apakah varian populasi dari ke- lompok yang dirancang homogen atau tidak homogen.

Uji homogenitas pada keterampilan menulis para siswa dan siswi diuji dengan menggunakan tingkat signifikansi sebesar 5\%.

\begin{tabular}{|c|r|r|r|}
\hline \multicolumn{4}{|c|}{ Tabel 16. Uji Homogenitas } \\
\hline \multicolumn{4}{|c|}{ Levene's Test Of Equality Of Error Variances ${ }^{\text {a }}$} \\
\hline $\begin{array}{c}\text { Dependent } \\
\text { Variable: }\end{array}$ & \multicolumn{3}{|c|}{ Students" Writing Skill } \\
\hline F & df1 & df2 & Sig. \\
\hline 1,500 & 3 & 80 &, 221 \\
\hline $\begin{array}{l}\text { Tests The Null Hypothesis That The Error Variance Of The Dependent Variable Is } \\
\text { Equal Across Groups. }\end{array}$ \\
\hline A. Design: Intercept + A + B + A* B \\
\hline
\end{tabular}

Berdasarkan hasil uji homogenitas diatas menunjukkan bahwa $\mathrm{F}_{0}=1,500$ and Sig. $=0,221$ (Sig. 0,221 > 0,05). Hal tersebut menggambarkan bahwa semua data adalah sampel yang homogen. Oleh karena itu dapat disimpulkan bahwa $\mathrm{H}_{0}$ diterima and $\mathrm{H}_{1}$ ditolak. Hal tersebut menunjukkan bahwa sampel dari populasi tersbut adalah homogen. Hasil tersebut dapat dilihat pada uji normalitas dan uji homogenitas yang digambarkan melalui hasil uji pada tabel diatas, dan dapat disimpulkan bahwa persyaratan pada penelitian ini dengan menggunakan ANOVA telah terpenuhi.

\section{Hasil Uji Hipotesis Penelitian}

Hasil uji normalitas dan uji homogenitas pada penelitian ini menunjukkan bahwa sampel dari populasi pada penelitian ini berada pada distribusi normal dan varian sampel tersebut adalah homogen. Oleh karena itu, uji hipotesis lanjut dapat dilakukan dengan menggunakan ANOVA. Analisa hasil data pada keterampilan menulis para siswa dilakukan dengan menggunkan ANOVA dua jalur. Penelitian tersebut dilakukan dengan menggunakan SPSS 21.0. Hasil ringkasan analisis data dengan menggunakan ANOVA dua jalur adalah sebagai berikut:

\begin{tabular}{|l|c|c|c|c|c|}
\hline \multicolumn{7}{|c|}{ Tabel 17. Hasil Uji Hipotesis Penelitian } \\
\hline $\begin{array}{l}\text { Dependent } \\
\text { Variable: }\end{array}$ & $\begin{array}{c}\text { Student" } \\
\text { Writing Skill }\end{array}$ & & & & \\
\hline Source & $\begin{array}{c}\text { Type III Sum } \\
\text { of Squares }\end{array}$ & Df & Mean Square & F & Sig. \\
\hline $\begin{array}{l}\text { Corrected } \\
\text { Model }\end{array}$ & $10859,251^{\text {a }}$ & 3 & 3619,750 & 21,505 &, 000 \\
\hline Intercept & 297748,959 & 1 & 297748,959 & 1768,953 &, 000 \\
\hline A & 6937,773 & 1 & 6937,773 & 41,218 &, 000 \\
\hline B & 1326,629 & 1 & 1326,629 & 7,882 &, 006 \\
\hline A * B & 450,253 & 1 & 450,253 & 2,675 &, 106 \\
\hline Error & 13465,546 & 80 & 168,319 & & \\
\hline Total & 342809,170 & 84 & & & \\
\hline $\begin{array}{l}\text { Corrected } \\
\text { Total }\end{array}$ & 24324,798 & 83 & & & \\
\hline a. R Squared $=, 446$ (Adjusted R Squared $=, 426)$ & & \\
\hline
\end{tabular}


Berdasarkan data pada tabel hasil uji hipotesis penelitian diatas, hipotesis penelitian dapat dijawab dan dideskripsikan pada hipotesis pertama, terdapat pengaruh yang signifikan dari teknik pengajaran terhadap keterampilan menulis siswa. Berdasarkan tabel di atas, dapat dilihat bahwa

Sig. $0,000<0,05$ and $F_{0}$ is 41,218 . Oleh sebab itu, maka hipotesis nol ditolak sedangkan alternatif hipotesis diterima. Hal tersebut berarti bahwa terdapat pengaruh yang signifikan dari teknik pengajaran terhadap keterampilan menulis siswa. Hal tersebut dapat terlihat bahwa siswa yang diajar dengan teknik four square writing yaitu (XA1=71,94), hasil tersebut lebih tinggi dari siswa yang diajar dengan teknik mengajar konvensional yaitu $(X A 2=51,21)$. Dengan kata lain, terdapat perbedaan hasil keterampilan menulis siswa yang diajar dengan teknik four square writing dan teknik konvensional.

Hipotesis kedua, terdapat pengaruh yang signifikan penguasaan struktur kalimat terhadap keterampilan menulis siswa.

Berdasarkan tabel ANOVA diatas dapat dilihat bahwa Sig. $=0,006<0,05$ dan $F_{0}$ is 7,882, hal tersebut berarti bahwa null hipotesis dan alternatif hipotesis diterima. Hal ini menunjukkan adanya hasil yang berbeda pada keterampilan menulis siswa, para siswa dan siswi yang memiliki penguasaan struktur kalimat dengan tingkat yang tinggi yaitu mendapatkan sebesar XB1 $=67,76$, sedangkan para siswa dan siswi yang memiliki penguasaan struktur kalimat dengan tingkat yang rendah mendapatkan sebesar XB2 $=54,43$. Dengan melihat hal tersebut dapat disimpulkan bahwa terdapat pengaruh yang signifikan dari penguasaan struktur kalimat terhadap keterampilan menulis siswa.

Hipotesis yang ketiga, tidak terdapat pengaruh interaksi yang signifikan dari teknik mengajar dan penguasaan struktur kalimat terhadap keterampilan menulis siswa. Sementara itu, R. Squared sebesar 0,426 yang berarti teknik pengajaran dan penguasaan struktur kalimat memberikan pengaruh sebesar $42,6 \%$ (R. Squared yang dikonversikan kedalam presentase) terhadap peningkatan keterampilan menulis siswa.

\section{Pembahasan}

Berdasarkan hasil penelitian dapat digambarkan kedalam beberapa interpretasi hasil keterampilan menulis dari setiap kelompok yang diberikan perlakuan teknik mengajar dan penguasaan struktur kalimat terhadap keterampilan menulis siswa kelas delapan Sekolah Menengah Pertama adalah sebagai berikut:

\footnotetext{
1. Terdapat pengaruh yang signifikan teknik mengajar terhadap keterampilan menulis siswa
}

Teknik mengajar memiliki pengaruh yang signifikan terhadap peningkatan keterampilan menulis siswa. Terdapat perbedaan peningkatan keterampilan menulis siswa yang diajar dengan menggunakan teknik mengajar four square writing dan konvensional teknik. Hal tersebut ditunjukkan dengan rata-rata skor hasil keterampilan menulis siswa yang diajar dengan menggunakan four square writing sebesar 71.94 dan sedangkan hasil rata-rata skor hasil keterampilan menulis siswa yang diajar dengan konvensional teknik sebesar 51.21. Teknik mengajar memiliki peran yang signifikan dalam meraih keberhasilan dalam belajar bahasa dan kegiatan belajar mengajar melalui penerapan teknik pengajaran yang tepat yang dapat mendorong dan meningkatkan motivasi siswa dalam pemerolehan keterampilan menulis yang baik. Hal tersebut selaras dengan Brown (2007:14) yang menyatakan bahwa "teknik adalah kegiatan khusus yang diwujudkan didalam kelas yang sesuai dengan metode pengajaran yang diselaraskan dengan cara penerapannya". Brown (2007:14) states," techniques were the specific activities manifested in the classroom that were consistent with a method and therefore were in harmony with an approach as well." Pengajar memerlukan beberapa teknik yang sesuai dan dapat diaplikasikan pada kegiatan pembelajaran yang dapat membuat para siswa dan siswi dalam pemerolehan keterampilan menulis sebagai keterampilan yang mudah dan menarik dalam proses penguasaannya.

Oleh sebab itu, teknik four square writing dipilih sebagai salah satu teknik mengajar yang terbaik dalam memfasilitasi para siswa dan siswi meningkatkan keterampilan menulis. Teknik four square writing memiliki tahapan-tahapan untuk mengembangkan ide-ide siswa dan siswi untuk membuat paragraf yang baik; teknik tersebut dapat membantu siswa dan siswi untuk mengorganisir ide-ide mereka, membuat kalimatkalimat pendukung dan mengembangkan semua kalimat yang ditulisnya menjadi rangkaian kalimat yang sempurna dan paragraf yang baik. Hal tersebut dapat membuat siswa dan siswi akan terbiasa untuk menulis secara sistematis dengan cara yang yang teroganisir dan merasa tertarik untu menulis.

\section{Terdapat pengaruh yang signifikan dari penguasaan struktur kalimat terhadap keterampilan menulis siswa. \\ Penguasaan struktur kalimat memiliki} pengaruh yang signifikan terhadap peningkatan keterampilan menulis siswa. Dengan kata lain, para siswa dan siswi yang memiliki pemahaman yang tinggi terhadap penguasaan struktur kalimat mendapatkan hasil yang lebih baik dibandingkan 
dengan para siswa dan siswi yang memiliki pemahaman yang rendah terhadap penguasaan struktur kalimat. Hal tersebut dapat dilihat dari skor rata-rata pada tabel deskripsi statistik diatas. Skor rata-rata keterampilan menulis para siswa dan siswi yang memiliki pemahaman yang tinggi terhadap penguasaan struktur kalimat adalah sebesar 67.76 , sedangkan rata-rata skor keterampilan menulis para siswa dan siswi yang memiliki pemahaman yang rendah terhadap penguasaan struktur kalimat adalah sebesar 54.43.

Penguasaan struktur kalimat adalah hal yang krusial untuk para siswa dan siswi yang belajar bahasa Inggris, karena hal tersebut merupakan aspek yang penting untuk dikuasai untuk keterampilan dalam berkomunikasi secara tertulis maupun secara lisan. Sejalan dengan Richard (2003:41) yang mengatakan bahwa. "struktur kalimat adalah frasa, klausa, atau kalimat yang dapat diterima karena mengikuti aturan dari tata bahasa". Richard (2003:41) says. "sentence structure mastery is a phrase, clause, or sentence that is accepTabel because it follows the rule of grammar". Dengan demikian, para siswa dan siswi harus memahami struktur kalimat dengan baik agar dalam menyampaikan pesan dan kalimat yang diatulisnya menjadi baik sehingga tersampaikan dengan sempurna kepada pembaca.

Oleh karena itu, penguasaan struktur kalimat adalah sangat penting untuk para siswa dan siswi yang ingin memilik kompentensi berkomunikasi yang baik, melalui pemahaman yang baik pada penguasaan konsep struktur kalimat; para siswa dan siswi dapat menghindari penggunaan struktur kalimat yang salah ketika mereka menyampaikan pesannya memalui paragraf atau teks yang ditulisnya.

\section{Tidak terdapat pengaruh interaktif yang signifikan pada teknik mengajar dan penguasaan struktur kalimat terhadap keterampilan menulis siswa.}

Berdasarkan penelitian yang dilakukan tidak terdapat pengaruh interaktif yang signifikan pada teknik mengajar dan penguasaan struktur kalimat terhadap keterampilan menulis siswa. Pembelajaran bahasa Inggris adalah salah satu bahasa asing yang diterapkan disekolahsekolah yang ada di Indonesia; bahasa Inggris digunakan untuk bahasa sehari-hari untuk berkomunikasi. Dalam mempelajari bahasa Inggris para siswa dan siswi harus menguasai empat keterampilan dasar; mendengarkan, berbicara, membaca dan menulis. Sebagai salah satu dari empat keterampilan berbahasa, menulis melibatkan beberapa komponen kebahasaan yaitu konten, organisasi, kosakata, tata bahasa dan mekanisme penulisan. Menulis melibatkan sis- wa untuk menyampaikan mengikuti beberapa proses seperti membangun pikiran mereka agar mereka dapat menyampaikan ide-ide mereka melalui tulisan. Tetapi ada banyak siswa dan siswi yang mengatakan bahwa menulis merupakan keterampilan yang sulit untuk dipelajari. Ada dua faktor utama yang mempengaruhi motivasi belajar siswa; faktor internal dan faktor eksternal.

Banyak siswa yang tidak memiiki motivasi dan keinginan untuk menulis, mereka harus mewujudkannya dengan daya yang kuat dalam memulai kegiatan menulis. Sejalan dengan Brown (2007:334) bahwa "belajar menulis adalah sebuah perilaku yang mirip dengan berenang". Brown (2007: 334) states that "writing is a learnt behavior that is similar to swimming. Orang berbicara layaknya perilaku alami mereka, tetapi tidak semua orang dapat menulis seperti layaknya berbicara. Keterampilan menulis harus dilakukan secara sadar dengan usaha yang keras. Para siswa dan siswi terus menerus mengeluh, mereka tidak dapat menulis dikarenakan tidak memiliki ide, tidak menguasai pembuatan struktur kalimat yang baik, dan tidak memiliki kosa kata yang cukup. Pada eksternal faktor, kurangnya kompentensi guru atau pengajar, teknik mengajar, sumbersumber pembelajaran, dan fasilitas sekolah. Kesemua faktor-faktor tersebut banyak berkontribusi pada tidak tercapainya pembelajaran dengan baik.

\section{SIMPULAN \\ Kesimpulan}

Terdapat pengaruh yang signifikan teknik mengajar terhadap keterampilan menulis siswa pada Sekolah Menengah Pertama Swasta di Bogor. Hal tersebut dibuktikan dengan tingkat signifikan sebesar Sig. $=0,000<0,05$ dan $\mathrm{F}_{0}$ is 41,218 .

Terdapat pengaruh yang signifikan penguasaan struktur kalimat terhadap keterampilann menulis siswa pada Sekolah Menengah Pertama Swasta di Bogor. Hal tersebut dibuktikan dengan tingkat signifikan sebesar Sig. $=0,006<0,05$ dan $\mathrm{F}_{0}$ is 7,882 .

Tidak terdapat pengaruh interaksi yang signifikan teknik mengajar dan penguasaan struktur kalimat terhadap keterampilan menulis siswa. Hal tersebut dibuktikan dengan tingkat signifikan sebesar Sig. $=0,106>0,05$ dan $F_{0}$ is 2,675.

\section{Saran}

Berdasarkan pada hasil penelitian di atas, peneliti ingin memberikan beberapa saran untuk guru, para siswa dan siswi, dan institusi. Pertama untuk guru, guru sebaiknya memberikan motivasi dan arahan kepada para siswa dan siswi secara intensif agar para siswa dan siswi termotivasi dalam mempelajari bahasa Inggris 
terutama dalam meningkatkan keterampilan menulis siswa. Dikarenakan menulis adalah salah satu keterampilan yang sulit, para siswa dan siswi sering kali mengeluh ketika diminta untu menulis. Hal tersebut berhubungan dengan cara guru mengajar untuk menulis. Dengan demikian, sebaiknya guru memberikan panduan bagaimana cara membuat tulisan dengan baik, para siswa dan siswi memerlukan banyak latihan menulis, dan penjelasan secara rinci tentang langkah-langkah menulis dengan cara yang menarik dan teroganisir agar para siswa dan siswi memiliki keinginan untuk latihan menulis. Para siswa dan siswi diharapkan akan merasakan semua pengalaman belajar yang menyenangkan dengan memotivasi mereka mengeksplorasi keterampilan menulis dan memiliki pengalaman yang menarik dalam proses belajar melalui teknik four square writing, para siswa dan siswi tidak akan bosan dengan diterapkan teknik four square writing dalam kegiatan pembelajaran, memunculkan rasa ingin belajar, membantu percepatan belajar mengajar agar berjalan dengan lancar. Kedua untuk para siswa dan siswi, proses kegiatan belajar mengajar membutuhkan dukungan dari guru maupun para siswa dan siswi. Para siswa dan siswi diharapkan untuk membangun motivasi yang bersumber dari dalam diri mereka sendiri dan dukungan dari luar, seperti dari guru, teman sekolah, dan orang tua. Dalam hal ini, para siswa dan siswi harus memiliki usaha yang kuat untuk belajar bahasa Inggris; terutama keterampilan menulis. Mereka harus mengekspresikan ide-ide dan pikiran mereka tanpa ada rasa keraguan tentang pendapat dari teman-teman yang lain yang meragukan keinginan belajar dan memusatkan perhatian pada penguasaan struktur kalimat. Dengan memperhatikan semua komponen tersebut para siswa dan siswi akan memahami penguasaan struktur kalimat dalam membuat sebuah tulisan. Ketiga untuk institusi atau sekolah wajib memperhatikan fasilitas kegiatan pembelajaran hal tersebut penting dalam mendukung proses belajar para siswa dan siswi. Oleh karena itu, sekolah wajib memberikan pelatihan untuk memberikan edukasi dan menambah wawasan baru mengenai berbagai macam teknik mengajar untuk dapat menjadi pengajar yang profesional dengan mengaplikasikan teknik mengajar yang sesuai untuk mencapai tujuan pembelajaran dan meningkatkan keterampilan menulis siswa.

\section{DAFTAR PUSTAKA}

Allen, W. S. (1979). Living english structure. London: Longman Group Limited.

Arikunto, S. (2006). Prosedur penelitian, suatu pendekatan praktek. Jakarta: Rineka Cipta.

Boyatzis, E.R., Scott, S. C. \& David, A. K.(1994).
Innovation in professional education: steps on a journey from teaching to learning. JosseyBass: John Wiley and Sons Ltd

Brown, D.H. (2007). First language acquisition: principle of language learning and teaching $5^{\text {th }}$ edition, New York: Longman.

Brown, H. D. (2007). Language assesment: priciples and classroom practices. White Plains, NY: Pearson Education.

Brown, H. D. (2000). Principle of language learning and teaching $4^{\text {th }}$ edition, Englewood Cliff. New Jersey: Printice Hall Regent.

Brown, H. D. (2001). Teaching by principle: an interactive approach to language pedagogy (second edition). New York: Longman.

Brown, H. D. (2007). Teaching by principle: an interactive approach to language pedagogy (third edition). New York: Longman.

Bruington, P. (1984). Get in writing. Colombus, Ohio: A Bell \& Howell Company.

Burrows, P. (2014). A creative approach to teaching grammar. London, UK: Bloomburry Imprints.

Emzir. (2008). Metodologi penelitian pendidikan: kuantitatif dan kualitatif. Jakarta: PT. Raja Grafindo Persada.

Fraenkel, J. R. \& Wallen. (2007). How to design and evaluate research in education, $6^{\text {th }} \mathrm{ed}$. New York: McGraw-Hill.

Gould, Gould and Mary F. B. (2010). Four square writing method. Dayton: A Lorenz Company.

Gallo, J. D., Rink, \& Henry W. (1968). Shaping college writing. New York: Harcourt, Brace and World Inc.

Greenbaum, Sidney and Quirk, \& Randolph. (1990). A students's grammar of the english language. Harlow, Essex: Longman Group UK limited.

Harmer, J. (1998). How to teach english. Harlow: Pearson Education.

Harmer, J. (2004). How to teach writing. Saffron Waldon, Essex: Pearson Education Limited.

Harmer, J. (2007). The practice of english language teaching. Harlow, Essex: Pearson Education Limited.

Huddleston, R. (1989). Introduction to the grammar of english. Newyork: Cambridge University Press.

Irmscher, W. F. (1987). Teaching expository writing. Orlando: Holt, Rinehart, and Winston Inc.

Jack, R. \& Theodore S, Rogers. (2003). Approaches and methods a language teaching. London:Cambridge University Press.

Joyce, H. D. S. \& Feez, S. (1998). Creative writing skills. Victoria: Pnoenix Education.

Kadir, (2010). Statistika: Untuk penelitian ilmuilmu sosial. Jakarta: Rosemata Sampurna

Kemper, Dave, Nathan, \& Ruth and Patrick S. 
(1984). Writers express. Winconsin: Write Source Educational Publishing House.

Legget, G., C. M., \& David and Melinda G. K. (1988). Handbook for writers (tenth edition). New Jersey: Prentice Hall Inc.

Merril, E. C. (1984). Get in writing. Ohio: A Bell \& Howell Company Colombus

Newby, M. (1988). The structure of english: hanbook english grammar. Newyork: Cambridge University Press.

New S. W. (2001). English k-6 modules. Sydney New South Wales: Board of Studies New South Wales.

NN.(1981). Grammar and writing (teachers' annotated edition grade 10). Newyork: Macmillan Puvlishing Co.,Inc

Orr, J. K. (1999). Growing up with english. USA: United States Departement of States.

Oxford University Press. Accessed $20^{\text {th }}$ June 2016. http://www.oxforddictionaries.com/

Phythian, B.A. (1999). English grammar. London: Hodder \& Stoughton Educational.

Reid, J. M. (1994). The process of paragraph writing (second edition). New Jersey: Prentice Hall Regents.

Rad F., Adrew., et al. (2009). Linguistics an introduction (second edition).Newyork: Cambridge University Press.

Rogers, H. (2005). Writing system: a linguistic approach. London: Oxford Blackwell Publishing.

White, V. Ronald et al. (1997). Process writing. Essex: Longman Limited. 